The changing discourse of city plans: rationalities of planning in Perth, 1955-

2010

Diana MacCallum

Curtin University of Technology, Perth, Australia

Diane Hopkins

University of the West of England, Bristol, UK

Corresponding author: Diana MacCallum

School of Built Environment

Curtin University of Technology

GPO Box U1987

Perth, WA 6845

AUSTRALIA

Email: diana.maccallum@ curtin.edu.au 


\title{
The changing discourse of city plans: rationalities of planning in Perth, 1955-
}

2010

\begin{abstract}
: ${ }^{\mathrm{i}}$
Plans are among the most durable products of planning, and as such offer a revealing window into the worlds of the planners of their time. In this paper we set out a methodology for viewing those worlds using critical discourse analysis (CDA). This method focuses on four key textual features of plans: construal of substance, construction of agency, generic structure, and presentation, enabling the investigator to go beyond thematic discourses and uncover the institutional, political and ideological role of planning during the time period in which plans are produced. We use this method to interrogate the changing rationalities governing planning in Western Australia since the Second World War by analysing the four major city plans for Perth, covering a period from 1955 to 2010 . This longitudinal analysis suggests that planning in WA mirrors concurrent trends in international planning theory, and highlights the significance of 'the plan' as an object of inquiry for revealing the changing nature of planning and planners over time.
\end{abstract}

Keywords: discourse analysis, metropolitan plans, strategic spatial planning; planning history; Western Australia 
The changing discourse of city plans: rationalities of planning in Perth, 1955-2010

\section{Introduction: discourse analysis, plans and planning research}

Discourse analysis - acknowledging the term's multiple meanings - is increasingly seen as a useful approach to understanding a range of issues in planning: power, knowledge, ideology, persuasion, social difference, and institutional framing, to name a few. A number of authors have specifically focused on planning texts as concrete realizations of discourses and discursive strategies (Collins, 1999; Hastings, 1999; Jacobs, 2004; Kumar and Pallathucheril, 2004;

MacCallum, 2008, 2009; Myerson and Rydin, 1994; Portugali and Alfasi, 2008; Tett and Wolfe, 1991; Throgmorton, 1991), drawing on a range of different approaches to show the relationship between language use and the ways that planning problems are framed and their potential solutions justified. In particular, these authors have used empirical evidence - in the form of texts and transcripts - to demonstrate the mythical and rhetorical nature of 'rationality' in planning, and the power struggles that lie behind dominant interpretations of urban and environmental issues, relationships and practices.

Most recently, there has been a spate of comparative interrogations of metropolitan-level spatial strategies published in Europe (Albrechts, 2004, 2006; Davoudi and Strange, 2009; Healey, 2007, 2008) and Australia (Bunker and Searle, 2007, 2009; Gleeson et al, 2004, Hopkins, 2008; Searle, 2004; Searle and Bunker, 2010). These studies show some interesting trends in thinking (on the part of both researchers and plan makers), for example: a blurring of the traditional distinction between process and product; a focus on strategic coordination in the city-region; reference to public or stakeholder participation to legitimize the plans; frequent use of a 'sustainability' discourse to frame strategic objectives; and a tendency (rhetorically at least) to depict space in 'relational' or 'network' terms - that is, as shaped by social relations and activities - rather than in 'essentialist'/Euclidean terms as a 'flat' container for land uses or functions. 
Thus, recent strategic plans seem to provide evidence for claims of a paradigm shift in contemporary planning. However, a puzzling gap remains in this evidence: there has been little systematic comparison of these recent plans with concrete examples from the past (from which, presumably, we are shifting). While many studies have focused on single plans (e.g. those in Davoudi and Strange, 2009), others have compared two consecutive plans for the same city (e.g. Searle, 2004) or contemporary plans for different city-regions (e.g. Gleeson et al, 2004; Healey, 2007). However, there is a virtual absence of longitudinal studies that examine plans for the same city-region over longer time frames. This lack may reflect a lack of tools within the planning discipline for analysing texts. Lees (2004) points out that most of the urban scholarship focused on discourse lacks any explicit discussion of methodology, either for analysing language or for connecting text analysis to broader social meanings and potentials for action. Greater attention to specific methods for analysing planning texts would therefore provide a useful contribution to urban research. To this end, this paper develops a framework for analysing planning documents across time, and illustrates the utility of that framework by applying it to the changing rationality of planning in Western Australia over a fifty-five year period.

Four major planning strategies for Perth, the capital city of Western Australia, have been published since the Second World War, providing snapshots of planning discourses and concerns from 1955 ('Stephenson-Hepburn'), 1970 (The Corridor Plan), 1990 (Metroplan), and 2010 (Directions 2031). This series of texts:

charts the progress and shifts in policy-making, the emergence of new ideas, the entwining of strategies, policies and actions. Key documents are fragments of different knowledgeframing processes. (Richardson and Jensen, 2003: 17)

In comparing the texts in this paper we focus less on their content (what they say) than on their modes of representation: that is, on how they construe key planning concerns of their times, including the roles of planning and planning knowledge in society. To do this, we use a form of critical discourse analysis, or CDA (Fairclough, 1995), which treats texts as points of entry into 
social phenomena. Within this broad methodology, we develop a focused analytical framework, which is used to compare the plans and identify shifts that have occurred in the institutional, political and ideological role of planning in Western Australia, contextualizing these with respect to concurrent trends in international planning theory.

\section{Discourse and social change}

CDA is particularly useful to the study of social change. Texts often constitute our only access to the past (Taylor, 1998: 4), not only describing events and conditions but also providing a snapshot of discourses and practices of their time: "Any discursive "event" (i.e. any instance of discourse) is seen as being simultaneously a piece of text, an instance of discursive practice, and an instance of social practice' (Fairclough, 1992: 4). Fairclough (2003) proposes a method of analysis which, while focusing closely on the linguistic features of texts, connects these with their broader institutional and cultural contexts through the analysis of 'orders of discourse' (after Foucault, 1971) - genres, discourses and styles. In particular, texts realize genres, the discursive aspect of regular practices: 'genre is how things get done, when language is used to do them' (Martin, 1985: 248). Genres are recognizable because members of a culture/institution share a knowledge of how language is used in certain settings. This means that texts of a particular genre, such as the 'strategic metropolitan plan', share identifiable characteristics related to the social work that they do: common structure, modes of expression and argument, systematic links with other texts (MacCallum, 2008; Martin, 1997). And, as society's expectations change with respect to institutional practices, the associated genres might also be expected to change (Fairclough, 2005). In addition, texts serve not only communicative purposes, but also performative ones (Austin, 1975; Searle, 1970): they may act directly on the world, bringing about their own forms of social change. Thus, decisions to adopt new textual modes and styles are also decisions to alter the discursive - and therefore the broader - practices which such texts realise. ${ }^{\mathrm{ii}}$ 
Thus, CDA marries detailed text analysis, using linguistic tools, with sociological consideration of context. In relation to governance and policy making, many genres (policy documents, parliamentary debates, educational/promotional materials, contracts, and so on) seem to be undergoing rapid changes in style and modes of representation ('discourses'), reflecting contemporary cultural and political shifts: simultaneous - and related - trends to 'conversationalization' and 'marketization', in Fairclough's assessment (1992, 1995; Sarangi and Slembrouck, 1996). In addition, genres traditionally associated with other realms of practice, such as 'stakeholder' meetings and business plans, are becoming increasingly incorporated into formal governance practices. That is, both the genres (activities) and the genre chains/networks (procedures) that realize 'governance' are increasingly 'hybridizing' with those of other fields, an aspect of the ongoing networking of institutions (Fairclough, 2005).

Our analysis of Perth's four metropolitan strategic plans focuses on how the documents realize these general changes, and others more specific to the location and the discipline, over the fifty-five year period that they cover. We necessarily concentrate on the texts themselves, though with some reference to known events, to identify the changing concerns and rationalities governing planning in Western Australia.

\section{A framework for textual analysis of strategic spatial plans}

Plans have been referred to as both the key tool of planners and the key discursive frame for planning (Tett and Wolfe, 1991). While there are many other forms of planning discourse policy documents, press releases, meeting minutes and planning 'talk' - plans are relatively selfcontained texts that can be directly compared from different time periods. In Western Australia the city plan has consistently remained a pivotal (if not always influential) part of the planning system (Bunker and Searle, 2009), unlike in other places such as the UK where the importance of plans has fluctuated since World War II (e.g. during the 1980s a project approach to planning was favoured over strategic plans) [Healey et al, 1997; Hall, 2002]). At this time, when there is 
renewed international interest in the strategic spatial plan (Healey, 2007; Davoudi and Strange, 2009), this paper concentrates on city plans in order to interrogate the changing rationality of planning in Western Australia.

The overall focus of this analysis is to highlight the relationship between shifts in planning practice in Western Australia and concurrent trends in international planning and theory. To do this, we ask a number of questions of the plans, centred on four key textual features: construal of substance, construction of agency, generic structure, and presentation (Table 1). Unlike most previous analyses of plans, which have addressed the substantive (material) and procedural themes of plans - for instance urban form or public involvement - our questions are oriented to understanding the broader roles of planning and planners in relation to other social actors in the political and public spheres - governments, public agencies, interest groups, and the 'public' (however construed - see Versteeg and Hajer, 2010). They interrogate the discursive means by which such actors (both individual and collective) and their actions (such as decisions) are - or are not - given agency, legitimacy and attention (cf. Forester, 1989, 1999).

The linguistic tools we draw on are aligned with Michael Halliday's theory of language as a 'social semiotic' (1978), a system for building and exchanging social meanings. Halliday's systemic functional grammar, or SFG (1985), analyses language as realizing meanings simultaneously in three functional dimensions: ideational (meanings about the world; what planners traditionally regard as the 'substantive'), interpersonal (relations between participants, orientation towards their subject), and textual (organizing information). Each of these 'metafunctions' is associated with a range of linguistic resources (see Eggins, 1994; Halliday, 1985). Linguistic resources broadly associated with each of our analytical categories are indicated in Table 1.

\section{[Table 1 about here]}

Substance: The rationality of a planning text is, in large part, a matter of how it represents its subject matter. We have focused on three key aspects of this rationality: 
- Claims about the role of the plan and of the information contained within it. Most planning texts give some attention to 'framing themselves', to justifying the need for land use regulations and the need for a new plan and explaining the basis for their substantive proposals.

- How the text construes causal and other logical relationships between phenomena. Planning texts connect urban problems with various demographic, social, economic, and environmental factors and also with preferable planning strategies, The types of connections they make can be identified through explicit conjunctions ('so'; 'however', 'therefore'; 'because' etc.) and relational processes (verbs such as 'become'; 'mean'; 'cause'; 'lead to' etc.). In addition, relationships are implicitly constructed through collocation - consistent or frequent juxtaposition of words to create text-specific (and discourse-specific) taxonomies of meaning (e.g. 'urban' + 'sprawl').

- What kinds of information are constructed as important and/or problematic. This is in part an organizational matter - a function of how much space is given to each type of information presented, and which are given prominence either as theme (generally, fronting a segment of text) or as point (final position in the segment, indicating new information) (Martin, 1992; and see 'generic structure' below). In addition, information and issues are problematised through modalisation (uncertainty - 'might', 'would', 'probably' etc.), deontic modulation ('must', 'should' etc.) and other forms of appraisal (opinions inherent in certain words - 'good', 'bad' etc. - see also 'agency' below).

Agency: Our second analytical category focuses specifically on how texts represent and confer power: rights and responsibilities in relation to the plan's concerns, including the right to opinions and judgement. Linguistic resources for construing responsibility and judgement include transitivity (who are framed as 'doing' and who are 'done to'), grammatical metaphor (for example, the use of nominalization to de-identify agents); naming/pronouns; projected thought or speech (' $\mathrm{X}$ is of the view that ...'); and appraisal. Appraisal, in particular, can be 
understood as performative not only of judgement, but also of identity. In institutional contexts, for example, officers are often expected to exercise professional ('performative', in Iedema and Grant's [2004] terms), rather than personal ('authentic'), judgements - these may be expressed through choices such as 'functional' (rather than 'fantastic', for example); 'issue' (vs. 'worry'), and so on.

These resources are examined in slightly different contexts to look at the roles and power of various actors on the planning stage:

- Agents of planning. We are interested in the author(s) of each plan, and the personal, collective and/or institutional responsibility they take for its recommendations - who is named, and how? What sorts of opinions are attributed to agents of the planning process?

- Agents of implementation. More broadly, how is responsibility assumed and conferred for the management and regulation of land uses? Where planners or planning agencies are invoked, what are their explicit and implicit roles and relationships with other actors, such as those in the political, corporate, and consumer spheres?

- Agents of history. The historical aspect of agency is important, because it concerns who/what has brought into being the present state of affairs. Thus, it helps to shape a text's representation of structural power, socio-natural relations, and opportunities for resistance or intervention.

- Other participants. In particular, we pay attention to how 'the public' and other 'stakeholders' are invoked in the texts: how they are characterized; what types of actions and processes they are associated with, and in what roles.

- The reader. Finally, we ask also whether the reader of the document is treated as an active participant in the metropolitan plan and, if so, in what role(s).

Structure: Our third category concerns how the text unfolds. Structure can be seen as both an argument and a metaphor for the planning process (MacCallum, 2008); as such it presents a 
particular basis for the plan's legitimacy. Three aspects of structure were considered in our analysis:

- Schema. The schematic organization of a plan is initially represented by the table of contents, which frames the reader's expectations of how the text/argument is developed. As information, written texts shift consistently from 'given' to 'new' knowledge (Martin, 1992); a generic schema therefore displays inherent assumptions about the shared knowledge, and sometimes the shared values, of its audience. As argument, texts shift from 'theme' to 'point'; the conclusion of each section (paragraph, chapter, sentence) provides a point of departure for the next, and the ultimate conclusion (traditionally, the recommendations) is legitimised by what precedes it (beginning, often, with a statement of shared goals or vision).

- Theme. Another important function of structure is that it gives emphasis to some themes over others. Positioning within a text provides for varying levels of attention and questionability. The first and final positions in a block of text (sentence, chapter, document) are the most prominent, after which, the earlier something appears the more noticeable it is. However, these prominent positions also make claims more open to challenge. Claims that are subordinated as circumstantial are less contestable (for example, following "X happened while Y was already going on”, it would be highly marked to question whether $Y$ actually happened).

- Cohesion/coherence. An important feature of texts - indeed, one of the reasons that an instance of discourse can be considered a 'text' at all (Eggins, 1994: p85-90) - is that semantic and textual links between sections make them recognizably 'about' something. These links include, for example, the repetition of related words and themes, and the retrieval of earlier words and themes through reference (largely through pronouns and deictics such as 'this'). 
Presentation: Extra-linguistic features also play important parts in the meaning of a text. Recently, there has been growing interest in imagery within planning research (Duhr 2003, 2007; Faludi, 1996; Healey, 2004a), particularly on how space (\& places) are represented visually, for example in plans and maps. Layout, graphics, colour and formatting contribute significantly to a text's ideational, interpersonal and organisational meaning: condensing or clarifying information, creating distinction through 'branding' and providing visual 'pointers' directing the reader's attention. Our analysis, therefore, includes consideration of how these resources work, particularly in relation to the plan's use of maps, illustrations, cover design and general layout/formatting.

The analysis of each plan within this framework is presented below, following a brief narrative of Perth's strategic metropolitan planning over the relevant time period.

\section{Strategic metropolitan planning in Perth}

Metropolitan planning in Australia is a state government matter, a tool for both growth management and attracting investment to the capitals. Bunker and Searle (2007) assert that, in spite of the obvious influence of international trends, there is a characteristic 'Australian paradigm' of strategic spatial planning, distinguished by its long-range plans, considerable land use detail, a reliance on private investment, and its role as a coordinating instrument for development and infrastructure. A number of factors underlie these features, notably: the broad powers of the states for both planning and infrastructure provision; the enormous dominance of the capitals in each state; strong population growth; the low-density living 'culture' of Australia; and a distinctive property development industry in which land development and building are separate activities. Perth might be seen as a paradigmatic realization of all these factors.

Perth is the capital city of Western Australia (WA) and has a population of approximately 1.6 million over an area of 5,000 $\mathrm{km}^{2}$ - a low-density city even by Australian standards, which has developed around a strong cultural identity centred on the 'Great Australian Dream' of 
owning a single detached house with a large backyard. The city's population has increased more than fourfold since the Second World War, largely associated with bursts of strong growth in the mining and resource development sectors. All four of the strategic (spatial) plans produced for Perth between 1955 and 2010 were initiated in times of significant economic and population growth. As a result, they all seek to manage and/or direct growth in line with planning trends of each period.

In 1953, Gordon Stephenson, academic and town planner/architect, was brought from the UK by the WA government to produce a plan for metropolitan Perth and Fremantle. Stephenson worked with Alistair Hepburn, the Town Planning Commissioner, to develop Perth's first strategic plan, the Plan for the Metropolitan Region (Stephenson and Hepburn, 1955), which became commonly known as the 'Stephenson-Hepburn Plan'. This plan then formed the basis for the development of the Metropolitan Region Scheme (MRS, 1963), a statutory instrument to control the growth of the city through zoning and release of land for development. An agency was established - the Metropolitan Region Planning Authority (MRPA) - with legislative authority to make decisions pertaining to the MRS.

The 1950s-60s was a period of rapid population growth. This growth also coincided with increasing popularity of the private motor vehicle, which dramatically modified the form of the city in ways not anticipated in the Stephenson-Hepburn Plan. A new plan was commissioned by the government in the late 1960s to address this sprawling growth. The resultant plan - The Corridor Plan for Perth (MRPA, 1970) - was produced 'in-house' by the Town Planning Department under the authority of the MRPA. The Corridor Plan sought to manage the city's growth by directing it along four corridors and was adopted by the MPRA with the approval of both major political parties. However, the plan was controversial. In early 1971 a new Labor government commissioned Paul Ritter, ex-chief planner for the City of Perth, to analyse and report on the Corridor Plan. The resulting report (Ritter, 1972) was highly critical of the Plan, but did not lead to any immediate review. Instead, the MRPA published a response to the 
criticisms, Report on the Corridor Plan for Perth (MRPA, 1972), justifying its earlier decision and explaining in more detail the reasoning behind it.

It was not until the late 1980s that the Corridor Plan was formally reviewed. The report of that review, Planning for the future of the Perth Metropolitan Region (Review Group, 1987), proposed a more compact form for the city, directing growth to infill areas and urban expansion to spaces adjacent to the corridors, rather than extending them further. At around the same time, structure plans for the four corridors were being produced by the government and taken out to communities for public consultation. One of the corridors, which proposed urban growth in a rural and water catchment area, was replaced in the review report by an alternative, which generated significant community opposition. ${ }^{\text {iii }}$ This opposition, and the changing political climate of the time, contributed to the breakdown of bipartisan support for the Corridor Plan, and for planning controls and processes more generally.

Metroplan (DPUD, 1990) was subsequently produced to replace the Corridor Plan. While it was presented as an 'adaptation' of the review report of 1987, it is an entirely different document, in both its content and its presentation. While it still stated urban consolidation as a key aim, it increased the area for urban expansion by approximately $30 \%$ from the review report, directing most of this additional area to extensions of the existing corridors. Most attention was given to the 'problem' of centralization of tertiary employment, in response to which Metroplan established a strong hierarchy of commercial centres supported by floor space targets and limits.

In the early 2000s another new Labor government, anticipating a 'third-wave' mining boom, proposed a review of Metroplan to cater for population growth of approximately 760,000 residents by 2031, representing a 50\% increase on Perth's 2001 population. The Minister for Planning established an extensive public and stakeholder engagement process to develop a new strategic plan for the city - 'Dialogue with the city'. This process lasted more than 12 months and included an 1100 participant public visioning forum and numerous stakeholder committees charged with the task of preparing a new, collaboratively formulated, plan for Perth (Hartz-Karp, 
2005). The new draft plan - Network City: community planning strategy for Perth and Peel (WAPC/DPI, 2004) $^{\text {iv }}$ - encouraged a more compact form for the city, in line with a view that continued low-density sprawl was the cause of many social and environmental problems. It introduced an urban growth boundary, a target of $60 \%$ infill for new housing, and a proposed pattern of development based on strong integration of land use with transport (Curtis, 2006). Network City was adopted in draft form in 2004 and released for a formal public comment period.

The WAPC did not immediately modify the strategy in response to the public submissions but rather produced a 'Statement of Planning Policy: Network City' in 2006 to confirm its status as the overarching metropolitan strategy for Perth. It was not until 2010 that Government endorsed a final plan, following the release of another consultation paper (DPI 2009) and another draft strategy, Directions 2031, for public comment in 2009 (State of WA 2009). That final document, Directions 2031 and Beyond (State of WA 2010), maintains but modifies the basic principles of Network City with respect to urban form: a reduced infill target of $47 \%$, and a pattern of development based on defined activity centres connected by a strong transport network. In a sense, Directions represents the pressing of its predecessor through a more conventional process, 'taming' it for the sake of easier implementation, as the draft document noted:

Network city is not a traditional spatial plan that can be used to inform and guide future growth of the region. Therefore, ... the Western Australian Planning Commission (WAPC)

... [identified] ... tasks required to transform Network City from a diagrammatic representation of urban growth principles into a spatial framework that establishes firm benchmarks, targets and directions for growth. (State of WA, 2009: 1)

Concurrent with these local events, international developments in planning theory and practice also influenced the plans' content, structure and style, as the analytical summaries in the following sections show. 


\section{Stephenson-Hepburn Plan (1955): the masters' masterplan}

Planning in the 1950s centred on the physical - the layout of land uses and the design of built form (Taylor 1998). The design emphasis of planning at this time manifested in comprehensive master plans that articulated desired end-states for cities and towns and were produced by 'wellknown, named, “experts”, acting as consultants' (Healey, 2008: 866). These 'blueprint' plans reflected a normative orientation to orderedness, realized for example by the separation of conflicting land uses through zoning (Taylor, 1998). Planning during the 1950s operated within the context of a political 'consensus' about the role of the state and the objectives of planning, though this occasionally proved to be illusionary (Meyerson and Banfield, 1955).

The Stephenson-Hepburn plan is typical for this time, with a named author whose personal voice is present throughout. Not only does Stephenson introduce the document in the first person (1-5), but also freely legitimizes the analysis with his (and, by implication, Hepburn's) own expert opinions and values, often using 'authentic' appraisal (Iedema and Grant, 2004) to do so:

The summers are most enjoyable, with almost unbroken sunshine for four months. (32)

The natural landscape of the Darling Ranges changed and enhanced by a large-scale engineering project. (Caption, figure 27, 80+)

Professional expertise is also implied in references to 'techniques and methods which were new ...' (1) and the constant use of tables and diagrams which illustrate analytical projections from current trends in population, traffic, employment and so on (see Figure 1). These projections are grounded in detailed, Perth-specific, usually quantitative information, which fronts both the plan as a whole (Chapters 1-5) and each of the thematic chapters (6-9):

Valid assumptions can be based only on past and present tendencies and policies, weighted where it is appropriate, in the light of foreseeable changes (37)

[Figure 1 about here] 
In addition, a separate 'atlas' of maps (A2 size) gives spatial expression to much of the background information, in preparation for the spatial expression of the plan itself. Thus, reading the generic structure as a metaphor for the planning process (MacCallum, 2008), StephensonHepburn presents as the outcome of a traditional Geddesian 'survey-analysis-plan' process (see Taylor, 1998: 62-67). The past is treated as given background to the present state of affairs, its agents largely deleted through the use of the passive voice and nominalizations:

Regret may be expressed at the passing of the trams. (128)

And the final product (this plan) is framed as 'conclusions concerning the future' (2).

In its future-oriented aspect, the Stephenson-Hepburn plan is a blueprint, an 'overall' (iii) desired end-state for Perth, with a detailed A1 colour map showing zoning proposals for the entire metropolitan area and detailed numerically-based standards for development. The foreword, by the Minister for Town Planning, explicitly connects the practices of design and planning:

I do not think anyone will quarrel with the principles of town planning. It is, after all, very logical when carrying out any work, be it building a house or a boat or a city or running a business, to look ahead, assess the difficulties and programme the work in accordance with a design or plan. (iii)

The above quote also illustrates an assumption, manifest throughout this document, of a 'common-sense' consensus surrounding both the 'principles of town planning' and the context for it. The role and obligation of the state to commission, administer and implement the plan is taken for granted; indeed, non-government actors are almost never mentioned in relation to future actions, and those of state government agencies are invoked without explanation. In contrast, local government authorities (differentiated by fixed boundaries) are conferred with roles, the 'detail' of local implementation contrasted explicitly with the 'broader' decisions of the state (241): a scaled hierarchy is established, to be crystallized in the statute recommended by the authors, the Metropolitan Region Scheme Act 1959. Through these means, the Stephenson- 
Hepburn plan re-creates the institution of 'planning' in WA - as both a structure and an agent, with situated powers, roles and conventions.

When other people are mentioned, they generally take the form either of 'the public' - this in relation to a need for (and assumption of) their support of the plan's content - or of idealtypical inhabitants whose (presumed) desires and needs inform specific proposals:

The needs of old people can be satisfied particularly well in single-storey terrace houses with small garden spaces. (148)

Shopping "in town” will always be popular. (179)

These references make it clear that, notwithstanding their discursive suppression of difference, the authors see the purpose of planning as meeting human needs and aspirations, particularly in relation to employment, housing and open space. Spatial categories (village, town, city, region) are described as 'communities', for whom particular levels of government work (e.g. 14-15).

Stephenson-Hepburn, then, is an excellent example of the masterplanning tradition, with its strong focus on spatially realised information and its background assumptions regarding the role of the State, planning expertise, and the community as the passive beneficiary of the planning project. At the same time, it shapes a particular Western Australian tradition whose traces continue to be manifest in the metropolitan plans that follow it.

\section{Corridor Plan (1970): Scientistic best practice}

The Corridor Plan was written at the peak of scientific-rationalist planning (Yiftachel and Hedgock, 1992), between the publication of the systems model (Chadwick, 1971; McLoughlin, 1969) and Andreas Faludi's (1973) Planning Theory, generally acknowledged as the archetypal exposition of the 'rational comprehensive' approach. However, this was also the time of the breakdown of consensus on the constitution of the public interest and the rise in protest movements, feminism, and environmental awareness. Radical experiments such as advocacy 
planning were being promoted from within the planning academy (Davidoff, 1965) as a response to the growing recognition of multiple 'publics'. Community consultation was institutionalized to a certain extent in the US and the UK (e.g. Committee on Public Participation in Planning, 1969), invoking influential critiques disputing the idea that participation was necessarily a reformist activity (e.g. Arnstein, 1969; Sandercock, 1978). While the planning academy was concerned with the objectives of planning, criticisms from practice focused on the inflexible nature of zoning plans. These criticisms led to the emergence of 'structure planning' - the creation of broad-brush 'plans' indicating future development only in general terms.

The Corridor Plan is profoundly different from Stephenson-Hepburn, realizing a paradigm shift away from 'planning as design' to 'planning as science' (Taylor, 1998). Strikingly, the plan itself is neither detailed nor comprehensive, but a schematic showing, in self-consciously abstract form, the general shape of future urban development (see Figure 2): a 'framework' for statutory decision making (2) rather than an end state.

\section{[Figure 2 about here]}

Equally obviously, the plan is much smaller - 58 pages (68 with appendices) rather than 315 - reflecting a greatly reduced emphasis on explicating location-specific information (a mere four pages summarizes changes since 1955). Instead, the Corridor Plan draws its authority from its dialogical connection with Stephenson-Hepburn itself (as suggested above), and from two other main sources. One is the recent Perth Regional Transport Study (Perth Regional Transport Study Steering Committee, 1970), itself legitimized in traditional scientistic terms by incidental reference to the qualifications of its 'director' Robert Nielsen, and to undefined 'analysis' and 'forecasting techniques' (6). More generally, the plan appeals to 'universal' principles, including the idea of corridor planning as international best practice, unproblematic statements about the purpose of planning (see below), and systematic assumptions about cause and effect:

If left to the operation of a free-market economy, offices will probably develop as a straggling outward extension of the central area along major highways ... 
In its overall structure, the Corridor Plan also presents as systematic, progressing through analytically discrete elements or stages of the planning process (purpose, background, objectives, strategy, implementation) ${ }^{\mathrm{vi}}$, rather than expounding on substantive themes (as in Stephenson-Hepburn). It also carefully separates past (as the agent-free 'base' for the plan), present and future in its self-description (Chapter 2), and uses highly consistent subheadings and formatting within each chapter. Thus, the plan's scientific logic of cause and effect is complemented by, and linked to, an institutional logic of means and ends.

This logic is put to work in relation to a single-minded vision of the 'public interest'. As the above quote indicates, the plan is explicitly interventionist, driven by a need to control the 'operation of the free market'. The key concern, though, fronting the exposition of the plan's 'primary purpose' in section 1.1, is 'maximum economic efficiency' (5). Throughout, alternative options are discounted by reference to cost and/or waste, and 'authentic' appraisal is entirely limited to describing the 'dangers' of urban sprawl - setting the stage for a theme that recurs, with varying levels of emphasis, in all plans since that time. In one of several highlighted (in boldface) 'intratextual framing' statements (MacLachlan and Reid, 1994), this purpose is linked not only with the Corridor Plan but with planning (as a discipline) more generally:

In future urban expansion, the first task of planning is to prevent a vast sprawl. Such centreless and sporadic urban scatter is expensive to develop and wasteful in its requirements for ... services. (8)

The concern with the abstract 'efficiency', rather than with concrete human needs, indicates a significant shift in the objects of planning. Similarly, the agents of planning - planners and plans - have also become abstracted in the Corridor Plan. The named 'author' is the Metropolitan Region Planning Authority (MRPA), which, though given human face through the listing of its members on the frontispiece, did not personally write the plan, but rather assumed authorship by endorsing it. The plan itself has become the agent of most future actions: 'building', 'allowing', enabling' preferred forms of development, and 'giving' people access to 
open space and services (pp. 18-20). 'Planning' is never presented functionally as a process or activity undertaken by identifiable people; where it appears (which is rarely), it does so in gerundial form, embedded in nominal groups, as in the quote above. Through such discursive means, responsibility for planning is reconstructed as entirely institutionalized - in the discipline, in the statutory authority, and in its products.

Most remarkably, another agent - the government - has become not simply abstracted in the Corridor Plan, but completelyinvisible. In spite of the noisy and controversial politics surrounding the release of the plan, the plan itself presents as apolitical, its only human participants - and these are very rarely invoked - codified authorities and service providers. The subsequent Report, indeed, brought this political framing to the surface, under the revealing heading 'Democracy in Planning':

Though Parliament is the supreme authority for resolving competing community objectives, in the main many decisions are made by Cabinet and are carried out by the public service or, where the issues are complex, by Boards, Tribunals, Authorities or Commissions to which Parliament delegates powers. The MRPA is an example of delegated authority. (MRPA, 1972: 10) $)^{\mathrm{vii}}$

This separation between politics and the business of planning is a paradigmatic feature of the rationalist tradition, which shaped the discourse of government planning at this time of broad political turmoil.

\section{Metroplan (1990): Our growth strategy}

Metroplan was produced at the height of political neo-liberalism, following two decades of interest within the academy concerning the relationship between planning, the state, and the market. The academy's concern with political economy and the distributional effects of planning (e.g. Harvey, 1985; Sandercock, 1976) was coupled with an emerging view of planning as essentially political (Forester, 1985; Healey, 1983), and of both knowledge and the public 
interest as socially constructed and contested. At the same time there was a growing mainstream recognition of complexity and the frequent failure of plans to deliver (Hall, 1980; Pressman and Wildavsky, 1973; Wildavsky, 1973), and the primacy of 'the plan' was reduced in favour of strategic agreements for joint action with the private development sector (Hall, 2002).

In Metroplan, the government returns to the foreground. The preface is not signed by the head of the statutory authority as in the Corridor Plan and the 1987 review report, nor even by the Minister responsible for planning as in Stephenson-Hepburn, but by the Premier herself, who describes the document as 'the Government's response to planning for future growth and change ...' (1). Within the document, future actions are attributed only to the Government (if to anyone at all), and, in contrast to Stephenson-Hepburn, are usually expressed in the first instance as lowintensity mental and verbal processes (support, encourage, etc.) rather than material ones: that is, they are deliberative acts, not concrete ones. ${ }^{\text {viii }}$ That is, Metroplan realizes and reproduces a shift in the role of Government: its political arm more directly involved than in the Corridor Plan, but now as 'steering not rowing', in accordance with a global trend to 'entrepreneurial governance' (Osborne and Gaebler, 1992).

Relatedly, Metroplan has a more explicitly political character than its predecessors. It addresses a public audience, branding itself with a self-conscious 'look', attractive colour graphics and a layout that particularly highlights future actions (see Figure 3). The preface emphasizes a consultation process: the plan has been 'adapted from the draft ...' (rather than 'written'), and 'reflects the input of more than one thousand individuals and organizations who submitted their comments and concerns to the draft Strategy' (1). ${ }^{\text {ix }}$ This is in marked contrast to the MRPA's response of publishing a report to address criticism of the Corridor Plan (MRPA 1971). Moreover, there is a strong assumption of solidarity between the plan's (unidentified) authors and the public, construed (in part) by the frequent association of positive appraisal with an inclusive subject, variously 'we', 'our community', and 'Perth': 
Perth is an exceptional place. In planning for the changes, we must not forget those things that make it special ... (3)

\section{[Figure 3 about here]}

Both this inclusive 'we' and 'planning' as an actor are consistently the subject of modulated verbs expressing obligation ('must', 'need to', 'should' etc.), as in the quote above. That is, the government (and its constituent public) is never (grammatically) portrayed as independently choosing its own direction; rather, it is subordinated to circumstances, in particular that of strong - and highly desirable, 'dynamic', 'exciting' - economic growth, which is the macro-theme of almost every thematic chapter as well as of the document as a whole. That is, Metroplan, unlike the review report on which it is 'based', is not an interventionist strategy, but a reactive one that binds Government to the imperative of supporting, rather than controlling, market-driven development. Its recommendations are not only 'soft', as indicated above, but generally positive responses to development: 'supporting', 'promoting', 'encouraging', 'pursuing' growth in various forms.

At the same time, the plan itself is given personal agency; it is the most frequent subject of material, mental and verbal processes, and almost the only subject of non-modulated verbs (though 'planning' and 'the Government' occasionally act in the future, as above and below). Metroplan 'aims' to achieve goals and objectives, 'acknowledges' and 'recognizes' trends, 'envisages' how planning directions will unfold, and 'endorses' and 'supports' strategies and actions. As such, it constructs itself not only as its own author, but also as a proxy agent for the public, shaping 'our' responses to the fact of, and need for more, rapid economic growth, particularly in the commercial and retail sectors - by far the most wordage is devoted to promoting a hierarchy of commercial centres.

While Metroplan assumes, to a remarkable degree, solidarity and consensus on economic growth, it is also the first of Perth's plans to explicitly recognise social diversity. Stephenson- 
Hepburn's ideal-type citizen is here replaced by a fragmented, differentiated public, whose variety of desires and conditions constitute new market opportunities:

Not everybody wants the same type of home. ... Planning for the future will aim to satisfy a demand for a much wider variety of houses in different locations. diversification of opportunities will enhance an exciting and vibrant city

Metroplan is explicitly a 'general framework for growth' (1) rather than a blueprint for planning intervention. It is also the first of the plans to expand its scope beyond the management of land use/provision and infrastructure, with chapters devoted to heritage and urban design, and a section in the introduction concerning how the plan aims to help, 'within its scope to do so' (12) to protect 'the environment'. This appears to reflect the increasing mainstream adoption of sustainability discourses in planning (Gleeson et al, 2004) at this time; the stated principles of Metroplan (12) explicitly address the 'triple bottom line' of environmental, social and economic concerns.

\section{Network City (2004) and Directions 2031 (2010): Shifting discourses}

In spite of its now status as a mere predecessor to the government-endorsed Directions 2031, this section pays particular attention to Network City, which governed spatial planning in Perth for five years and which in many ways represented a significant departure from conventional planning norms. We return to Directions throughout this section, briefly commenting on key points of textual difference from Network City, and what those differences might mean for the next phase of Perth's development.

By the early 2000s, the 'interpretive, communicative turn in planning theory' (Healey, 1997: 28) was firmly established - some would say dominant (Huxley and Yiftachel, 2000; Yiftachel and Huxley, 2000) - in the academy. This entailed an understanding of knowledge, social relations, ethics and rationality as constructed through discourse, as well as a normative commitment to participatory democracy, at least insofar as this meant the inclusion of affected 
people in informed, principled decision making. In the US, normative frameworks emerged from a view of planning as negotiation and consensus building (Innes, 1996, 2004; Innes and Booher, 2003; Susskind et al. 1999). In analytical work, a constructivist epistemology gained ground with more attention to case studies - situated realizations of planning in place - rather than the 'grand theories' of political economy. Attention turned to social institutions and institutional capacity (Healey, 2005a, b, 2007; Healey et al, 2002), complemented by increasing reference to 'governance' as a framing idea (Coafee and Healey, 2003; Hajer and Wagenaar, 2003; Healey, 2004b) for understanding planning agencies' engagement with partners in the private and civil sectors. Critiques of the communicative focus of the 1990s (Tewdwr-Jones and Allmendinger, 1998; Yiftachel and Huxley, 2000) were accompanied by calls for a return to the physical focus of planning - a 'spatial turn' (Davoudi, 2009) which would place attention back on the product ('the plan') and outcomes of planning. Traditional land-use plans lost traction in favour of 'spatial' plans which provided strategic frameworks for a broad range of place-related issues (Albrechts, 2004), increasingly informed by a relational view of geography, with space shaped by networks of social relations and activities (Graham and Healey, 1999).

Network City, as the Minister for Planning and Infrastructure states in the foreword, is the product of an extensive community engagement exercise, 'Dialogue with the city'. It is also the work of a team of (personally anonymous) professional planners, subject to direct input by the responsible minister and her advisors (Hopkins 2010; Albrechts, 2006). These multiple origins are reflected in a text that is full of tensions and ambiguities. As this section shows, while presenting itself as the product of consensus building, and placing enormous emphasis on the ideas of 'community' and 'participation' (its subtitle is 'community planning strategy for Perth and Peel'), Network City discursively treats the 'community' as subordinate, and participation as a planning method. Although claiming to be visionary and interventionist, its concrete proposals for the future contain almost no reference to material change. And despite its use of 'network' terminology in its spatial aspect, it proposes a Euclidean containment of the metropolitan region. 
The macro-theme for Network City, established at the start of the Minister's foreword and echoed throughout the plan, is that of participatory governance. Following a brief ( 2 page) introductory chapter explaining the plan's background, the plan proper begins with a statement of 'four basic tenets of good planning', the first of which is 'dialogue', to be 'conducted in an open and inclusive manner' (4). And throughout, the plan's legitimacy claims for its substantive proposals are based not on information (as in Stephenson-Hepburn), scientific method (Corridor), or assumed consensus (Metroplan), but on the consensus building exercise that preceded its publication:

Perth's planning strategy responds to the views of Perth's residents ... (11)

A fundamental issue identified at the Dialogue with the city in September 2003 was .... (20)

These in-text references to a participatory 'dialogue' represent a significant development from Metroplan's reference - restricted to the preface - to a formal review-and-comment consultation process. Moreover, an entire chapter, Chapter 2, is devoted to the plan's implementation through ongoing governance processes. This is second only to the exposition of the spatial plan itself, preceding the detail on all 'substantive' themes (livability, economy, environment, transport and infrastructure coordination).

However, on closer analysis, the past and future roles that the document confers on the public (also 'the community', 'Perth's residents', 'people') and local government are rather limited. As the above extracts illustrate, the public tends to be embedded in nominalizations ('the views of Perth's residents'; 'Dialogue with the city'), objectified as a source of information for planning decisions. As subjects, the public's role is limited to mental processes of desire, usually projected by verbal processes ('indicated that they wanted'), empowered only to speak, rather than to decide or to act $(*$ decided; *planned). That is, in spite of the undeniable effort of inclusion that the Dialogue represented, it is treated as an effort of consultation, rather than active participation in the production of knowledge, space or governance institutions (cf. Hopkins 2004), a 'lower' level of involvement on most empowerment scales (Arnstein, 1969; 
IAP2, 2007). Similarly, although the document assiduously avoids an exclusive subject ('we without you') as the agent of planning, 'public involvement' and 'community engagement' largely feature as procedural elements, something undertaken by the State government acting upon others. This is indicated by the transitivity of its principles, for example:

... ensuring participants are representative of the population ... providing opportunities for participants to fully understand the issues ... ensuring participants have the capacity to influence policy and decision making. (28)

There is also a tension between the document's obvious emphasis on the ongoing roles of local government and the public in implementation, and a pervasive sense of hierarchy reproducing the structural achievement of the Stephenson-Hepburn plan - in which these actors are subordinated to the State: visually (see Figure 4) and as the objects of a consensus-enforcing education:

In working towards our vision, it is anticipated that all elements of our community will share the same values ... (4)

The principles of long term, sustainable planning need to be understood by the whole community (29)

\section{[Figure 4 about here]}

Directions 2031 eliminates these tensions by eliminating altogether the invocation of public involvement as its legitimacy base. In stark contrast to Network City, the people of Perth are posited as subjects only in the plan's vision, and the document does not mention the public involvement in creating this vision - nor is it clear that it comes directly from Network City. The preferred growth scenario is justified on abstract principles - in particular to sustainability, efficiency, precedent, best practice - and unattributed 'preferences', rather than the stated will of the public:

The connected city model is preferred because: A more compact city is desirable. (27) 
Otherwise, the public are mostly treated as beneficiaries of 'good' planning and urban design rather than active participants in governance. Public involvement in the implementation of the plan is both non-specific and subordinated to traditional stakeholders:

Engage with the development industry, state government agencies, local government and the community to implement the strategy. (73)

The above excerpt is actually the only reference to community engagement in the plan, with the focus of implementation on 'encouraging' local government to take responsibility for meeting “... their community’s part of a larger regional infill obligation.” (91).

Another tension manifest in Network City is in its presentation of its own intervention: ... this new direction will require the redesign of both governance structures and their supporting processes .... (23);

but:

... the Implementation: Governance and Process chapter outlines how the objectives can be most effectively and efficiently achieved without reinventing the legislative and regulatory framework. (3)

Such surface contradictions challenge the coherence of the document, and reflect a fragmented authorship in which chapters were written by different working groups before being authorised by Government. This is also evident in the style and tone of the chapters, which, though using the same internal headings, seem to interpret those headings in contrasting ways. Another source of tension here is that the document goes well beyond the traditional concerns of planning to include objectives about social and cultural capital, local identity, employment growth, education, security, biodiversity protection and, of course, governance. The scope of its vision is all-encompassing:

This chapter considers what is required to make Perth the world's most liveable city by 2030 . (35, emphasis added)

While this enlarged strategic scope might be considered typical for its time, a feature of the new 'environmental' planning (Gleeson et al, 2004), it creates internal conflict because it extends 
into the statutory mandate of agencies other than the Department of Planning and Infrastructure or (to put it another way) into the portfolios of other ministers. The formal governance system and the habitus of many of its employees - lags behind the changing culture of planning.

Although Directions 2031 also has a wide-ranging scope under the presentation of issues and principles (authorised by a 'sustainability' discourse), and includes many recommendations outside the traditional scope of planning, the more detailed or 'ready-to-go' actions are mostly limited to land use and development. Relatedly, the structure of the Directions 2031 document rejects the thematic organization of issues, strategies and actions in Network City, and returns to a more traditional format, a hierarchical organization beginning with overarching themes and strategies and then moving to more detailed actions and monitoring activities (MacCallum, 2008).

The presentation of both the Network City and Directions 2031 documents illustrate attempts to present a 'public face' for the plans, using attractive layouts and graphics (Hopkins 2008, n.p.). However, the language of Network City - particularly that of its recommendations is highly bureaucratic: complex, lexically dense and impersonal (Farmer, 1995; Iedema, 1997; Sarangi and Slembrouck, 1996) and Directions, although more straightforward, still uses highly technical language. Directions also has an enhanced presentational quality (Figure 5), with a greater amount and more sophisticated use of graphic material, and the highlighting of future actions (as "way forward”).

\section{[Figure 5 about here]}

Finally, both Network City and Directions 2031, as spatial plans, appear to be founded on a more 'relational' view of space (Healey, 2004a; Davoudi, 2009) than their predecessors, presenting the urban fabric as a connected network of 'activity centres' and 'activity corridors', and indicating in a general way that networks can extend beyond the limits of the metropolitan area (Figures 4, 5). The network terminology is explicitly made social on Network City's plan, which states that 'Activity centres bring people together' and 'Networks connect people and 
places' (13, Figure 4). However, once again, a fragmented authorship seems to undermine this relational view. In addition to the key recommendation of establishing an urban growth boundary to contain development, the following extract's reference to 'functions', 'scale' and 'hierarchy' suggest an essentialist approach:

Centres perform different functions and have different designations applied to them .... The scale of each centre and its associated designation requires further analysis to determine its place in the hierarchy of centres. (14)

Moreover, the framing of the spatial plan in 'network' terms is purposeful, its aims expressed in instrumentalist language as to 'optimize' land use and transport integration (14; Curtis, 2006). It is unlikely, therefore, that it represents a true epistemological shift (cf. Gonzalez, 2008 on Milan; Healey, 2007). And in Directions, through which the network plan will be implemented, the activity centres are more explicitly functional; their social aspect largely lost in favour of zoning proposals. Relatedly, the spatial plan, as a graphic, is more representational and less conceptual than Network City's, with locations of centres identified and named rather than indicative.

Taken together, Network City and Directions 2031 represent an eight year metropolitan planning project, in which a range of discourses come into rather uneasy contact. Network City's apparent embrace of communicative planning principles has been replaced in its successor by what are presented as practical considerations about managing growth within the parameters of the existing city and, to achieve this, adoption of an assumed - rather than pragmatically constructed - consensus on a range of principles about urban form.

\section{Discussion: changes and continuities in WA planning}

Table 2 presents a summary of a few key features of each document. In particular, we emphasize developments in relation to: the nature of the plan; roles of planners, the government and the 'public'; the construction of space; and legitimacy claims. 


\section{[Table 2 here]}

This analysis brings out a number of progressions which are clearly related to trends in international planning thought, as well as to a broader societal blurring of public and private institutions and discourses. Between the 1955 and 1970 documents there is a startling shift of emphasis from detailed local information, synthesised by an acknowledged expert, to a kind of generalised rationality, whose universality is accentuated by the institutionalization of authorship, and the anonymity of any individual writers . It is also at this time that economic goals begin to replace social ones as the dominant concerns of the plan, though in 1970 these were still framed in terms of a public interest that differed from that of the private sector, and an assumed (but, by 1970, contested) consensus on the role of the state, the authority of 'expertise' and the nature of knowledge (cf. Fischer, 2000).

In the later documents that consensus has been supplanted by others, more abstract and less grounded in the traditions of the public service. The 1990 and later plans realise globally circulating discourses from the worlds of politics and business about the desirability of economic growth, sustainable development, social diversity or (in Network City's case) participatory democracy, reflecting the increasing scope and overt politicization of planning's 'policy ambit' (Gleeson et al, 2004: 351). Network City/Directions 2031, the latest metropolitan plan for Perth, is explicitly a spatial strategy, a management framework which assumes a need to respond dynamically to socio-economic changes affecting the urban form and fabric, and which acknowledges a range of interdependencies between land use planning and other areas of government responsibility. Like Metroplan, they explicitly use rhetorical devices and graphic design to 'sell' their message, addressing a broader, less specialised public than the earlier texts.

There are, however, also clear continuities. One relates to the ongoing production of the Western Australian model of planning: specific hierarchies, roles, responsibilities and practices established in Stephenson-Hepburn, crystallized in the Metropolitan Region Scheme Act, and progressively sedimented in the subsequent plans. Urban planning is reified not only in 
linguistic texts, governance structures and development traditions (cf. Bunker and Searle 2009), but also, even more durably, in hard buildings and infrastructure; it displays a high degree of path dependency which explicitly constrains and shapes local and regional practice:

The present urban and rural form ... is the base from which the future development of the Region and the coastal plain must be projected. (Corridor Plan: 16)

The framework ... acknowledges that we have to work with the city we have. (Directions 2031: v).

Another, more general continuity is a notion of history as agent-free, its relevance contained in how it has led to current conditions. Relatedly, and in spite of demonstrably changing relationships between planners and their political co-actors in urban development, a notion of planning as a technical activity continues to influence how it is practised. Technical registers, which tend to present processes as relationships of cause and effect (Halliday and Martin, 1993), dominate all the documents, giving them a rationalist flavour even in the face of internal contradictions and openly political statements. Even community consultation and engagement are discursively treated as techniques, as 'things' to be controlled by the agents of planning. Indeed, the most explicitly constructivist and public-driven of the documents, Network City, was radically altered in favour of a more technical, anonymous expert-driven approach before the final plan, Directions 2031, was endorsed by the government of the day; while many political and practical factors affected this outcome, it also suggests that a kind of 'epistemological anxiety' (Innes and Booher, 2010: 173) continues to place limits on the scope and pace of institutional change in planning.

\section{Conclusion: CDA in planning research}

These features, and the significant tensions that they represent, are present in the detail of the texts. They have been brought to the surface by a fine-grained text analysis, guided by a socially-oriented understanding of language, and a set of framing questions focused on the 
semiotic construal of problems, actors, relationships and practices. As such, they demonstrate the value of CDA as a unique lens for interrogating government practices, power relationships, and constructions of rationality; for 'showing connections and causes which are hidden' (Fairclough, 1992: 9); in short, for escaping from taken-for-granted wisdom. More specifically, the analytical framework presented and illustrated here provides focus to the question of exactly how plans and policies 'mean' (Yanow 1996): that is, how they realize the discourses, practices and rationalities of their time and place.

We recognize the limitations of text analysis in terms of understanding plan-making in all its messy detail: as Richardson and Jensen point out, texts need 'to be placed within the context of a live policy process' (2003, p.19). Retrospective analyses of plans and processes cannot be 'live'; instead they must rely upon historical accounts, usually themselves documentary - text books, case study reports, and so on (see Taylor, 1998). Moreover, text analysis cannot by itself address the important question of how plans actually influence material development of a city. Nonetheless, we believe that planning texts provide a valuable source of evidence about what planning was like in the past, and should be referred to in support of historical claims about the discipline. This paper has, for the first time, offered a framework for comparing plans directly over a significant period of time, not only in their material content, but in their procedural, epistemological, normative and socio-political foundations. By treating planning texts as instantiations of planning and wider discourses - and, in turn, as realisations of disciplinary and other social practices - we can make broad sense of their lexico-grammatical detail, not only in the ideational (substantive) dimension but also in their interpersonal and organisational aspects. This gives us a unique opportunity to apply established concepts and proven grammatical tools to tease out implicit meanings that might be opaque to a less systematic form of analysis, thereby allowing us to interrogate directly how rationalities and institutions of governance, including planning, are produced in their textual artefacts. CDA, appropriately guided by pertinent questions, is thus a useful addition to the methodological repertoire of planning scholarship. 
Thanks to the anonymous reviewers for their helpful comments on the draft of this paper. Thanks also to Garry Middle and Curtin's Planning Theory students of 2005-2006, who participated in this exercise when it was first conceived, and thereby helped us to develop the idea.

ii Fairclough, adopting a critical realist approach (2003; Fairclough et al, 2004) rejects the characterization of texts as solely performative; he maintains a distinction between texts' construal of the social world and their construction of it, reflecting an ongoing concern with the dialectics of structure and agency.

iii The review report dealt with the reasons for the change in a small number of dot points (six negative, five positive) pointing out costs and opposition from residents (Review Group 1987, 99). The alternative corridor was dissected by the policy-protected agricultural area of the Swan Valley, and became the subject of extensive consultation and lobbying efforts throughout the 1990s (see Healey and Hillier 1996; Hillier 2000, 2002).

iv $\quad$ The scope of the plan included the Peel region to the south of the city because Perth had grown significantly since the early 1990s and had encompassed the regional town of Mandurah in the Peel region. v Following the consultation phase, it was considered that 2031 was an appropriate planning horizon, but that the State also needed to look 'beyond that date to ensure that the city is able to respond in a sustainable way to longer term growth pressures.' (State of WA 2010: v). The document's subtitle, 'metropolitan planning beyond the horizon', is strangely reminiscent of Jean Hillier's (2007) poststructuralist theory of planning.

vi The Report goes further, presenting explicitly the planning methodology, including the systematic elimination of less desirable alternative solutions.

vii The Report differs significantly from the Corridor Plan, in that the MRPA is present throughout as an active actor, thinker, feeler, speaker. The authority's agency - their responsibility for the decision to endorse the Plan and reject the Ritter report - is openly stated. Still, the actual new government (as opposed to its institutions, Parliament and Cabinet) remains invisible here.

viii Even where recommendations are material processes, these tend to be 'soft', abstract rather than concrete: 'collaborate', 'consolidate', 'develop strategies', etc.

ix Metroplan is certainly substantially different from the draft Metropolitan Strategy (Review Group 1987), which is explicitly written by individual planners according to a stated process of data collection, objectives development, and analysis of alternative strategies. The 1987 report also lacks the fancy presentation of Metroplan; it is printed in a single colour and its graphics are limited to spatial and tabulated presentation of data and projections. 


\section{References}

Albrechts, L. (2004) Strategic (spatial) planning reexamined. Environment and Planning B: Planning and Design, 31, pp. 743-758.

Albrechts, L. (2006) Shifts in strategic spatial planning? Some evidence from Europe and Australia, Environment and Planning A, 38, pp. 1149-1170.

Arnstein, S. (1969) Eight Rungs on the Ladder of Citizen Participation, Journal of the American Planning Association, 35, pp. 216-224.

Austin, J. (1975/1962) How to Do Things with Words (Oxford, Oxford University Press).

Bunker, R. \& Searle, G. (2007) Seeking certainty: Recent planning for Sydney and Melbourne, Town Planning Review, 78(5), pp. 619-42.

Bunker, R. \& Searle G. (2009) Theory and Practice in Metropolitan Strategy: Situating Recent Australian Planning, Urban Policy \& Research, 27(2), pp. 101-116.

Chadwick, G. F. (1971) A Systems View of Planning: Toward a Theory of the Urban and Regional Planning Process (Oxford, Pergamon).

Coaffee, J. and Healey, P. (2003) 'My Voice: My Place': Transforming urban governance, Urban Studies, 40(10), pp. 1979-1999.

Collins, C. (1999) Applying Bakhtin in Urban Studies: The Failure of Community Participation in the Ferguslie Park Partnership, Urban Studies, 36(1), pp. 73-90.

Committee on Public Participation in Planning (1969) People and Planning (London, Ministry of Housing and Local Government).

Curtis, C. (2006) Network City: Retrofitting the Perth Metropolitan Region to Facilitate Sustainable Travel, Urban Policy and Research, 24(2), pp. 159-180. 
Davidoff, P. (1965) Advocacy and pluralism in planning, Journal of the American Institute of Planners, 31, pp. 422-432.

Davoudi, S. 2009. Asymmetric development in spatial planning: positivist content and postmodernist processes? In Davoudi \& Strange (eds.).

Davoudi, S. \& Strange, I. (eds.) (2009) Conceptions of Space and Place in Strategic Spatial Planning (London, Routledge).

Davoudi, S. \& Strange, I. 2009. Space and place in twentieth-century planning: an analytical framework and an historical review. In Davoudi \& Strange (eds).

Department for Planning and Infrastructure. 2009. Building a Better Planning System Consultation Paper. Perth: Department for Planning and Infrastructure.

Department of Planning and Urban Development (1990) Metroplan: A planning strategy for the Perth Metropolitan Region (Perth, Department of Planning and Urban Development).

Duhr, S. (2003) Illustrating spatial policies in Europe, European Planning Studies, 11(8), pp. 929-948.

Duhr, S. (2007) The Visual Language of Planning: Exploring Cartographic Representations for Spatial Planning in Europe (London, Routledge).

Eggins, S. (1994) An Introduction to Systemic Functional Linguistics (London, Pinter).

Fairclough, N. (1992) Discourse and Social Change (Oxford, Polity Press).

Fairclough, N. (1995) Critical discourse analysis: the critical study of language (London, Longman).

Fairclough, N. (2003) Analysing Discourse: Text Analysis for Social Research (London, Routledge).

Fairclough, N. (2005) Critical discourse analysis in transdisciplinary research. In R. Wodak \& P. Chilton (eds.) A New Agenda in (Critical) Discourse Analysis (Amsterdam, John Benjamins). 
Fairclough, N., Jessop, B. \& Sayer, A. (2004) A critical realist interpretation of the effectivity of the production of meaning. In J. Joseph \& J. Roberts (eds.) Realism, Discourse and Deconstruction (London, Routledge).

Faludi, A. (1973) Planning Theory (Oxford, Pergamon).

Faludi, A. (1996) Framing with images, Environment and Planning B: Planning and Design, 23 (2), pp. 93-108

Farmer, D. J. (1995) The Language of Public Administration: Bureaucracy, Modernity, and Postmodernity (Tuscaloosa, University of Alabama Press).

Fischer, F. (2000) Citizens, Experts and the Environment: the Politics of Local Knowledge (Durham, Duke University Press).

Forester, J. (1985) Critical Theory and Planning Practice, in J. Forester (ed.) Critical Theory and Public Life (Cambridge, Mass, MIT Press).

Forester, J. (1989) Planning in the Face of Power (Berkeley, University of California Press).

Forester, J. (1999) The Deliberative Practitioner: Encouraging Participatory Planning Processes (Cambridge, MA, MIT Press).

Foucault, M. (1971) L'ordre du discours (Paris, Gallimard).

Gleeson, B., Darbas, T. and Lawson, S. (2004) Governance, Sustainability and Recent Australian Metropolitan Strategies: a socio-theoretic analysis, Urban Policy \& Research, 22(4), pp. 345366.

Gonzalez, S. (2008) (Dis)connecting Milan(ese): deterritorialised urbanism and disempowering politics in globalising cities, Environment and Planning A, 41(1), pp. 31-47.

Graham, S. \& Healey, P. (1999) Relational Concepts of Space and Place: Issues for Planning Theory and Practice, European Planning Studies, 7(5), pp. 623-646.

Hajer, M. A.\& Wagenaar, H. (eds.) (2003) Deliberative Policy Analysis: Understanding Governance in the Network Society (Cambridge, Cambridge University Press). 
Hall, P. (1980) Great Planning Disasters (London, Weidenfield and Nicholson).

Hall, P. (2002) Cities of Tomorrow: An Intellectual History of Urban Planning and Design in the Twentieth Century (Oxford, Blackwell).

Halliday, M. A. K. (1978) Language as social semiotic: The social interpretation of language and meaning (London, Edward Arnold).

Halliday, M. A. K. (1985) An Introduction to Functional Grammar (London, Edward Arnold).

Halliday, M. A. K. \& Martin, J. R. (1993) Writing Science: Literacy and Discursive Power (London, The Falmer Press).

Harvey, D. (1985) The Urbanization of Capital (Oxford, Blackwell).

Hartz-Karp, J. (2005) A case study in deliberative democracy: Dialogue with the city, Journal of Public Deliberation, 1, pp. 1-15.

Hastings, A. (1999) Analysing Power Relations in Partnerships: Is There a Role for Discourse Analysis? Urban Studies, 36(1), pp. 91-106

Healey, P. (1983) Local Plans in British Land Use Planning (Oxford, Pergamon).

Healey, P. (1997) Collaborative Planning: Shaping Places in Fragmented Societies (Houndmills, MacMillan Press).

Healey, P. (2004a) The treatment of space and place in the new strategic spatial planning in Europe, International Journal of Urban and Regional Research, 28, pp. 45-67.

Healey, P. (2004b) Creativity and Urban Governance, Policy Studies, 25(2), pp. 87-102.

Healey, P. (2005a) Collaborative Planning: Shaping Places in Fragmented Societies (Houndmills, Palgrave MacMillan).

Healey, P. (2005b) On the project of 'institutional transformation' in the planning field: commentary on the contributions, Planning Theory, 4(3), pp. 301-310.

Healey, P. (2007) Urban Complexity and Spatial Strategies: Towards a Relational Planning for Our Times (Abingdon, Routledge). 
Healey, P. (2008) Knowledge flows, spatial strategy making, and the roles of academics, Environment and Planning C: Government and Policy, 26, pp. 861-881.

Healey, P., de Magalhaes, C., Manadipour A. and Pendlebury, J. (2002) Shaping City Centre Futures: Conservation, Regeneration and Institutional Capacity: Regeneration in Grainger Town, Newcastle (Newcastle, Centre for Research in European Urban Environments, University of Newcastle).

Healey, P., Khakee, A. Motte, A. \& Needham, B. (eds.) (1997) Making Strategic Spatial Plans: Innovation in Europe, (London, UCL Press).

Hillier, J. (2007) Stretching Beyond the Horizon: A Multiplanar Theory of Spatial Planning and Governance (Aldershot: Ashgate).

Hopkins, D. (2004) Deliberative democracy in planning practice: important departures from theory, paper read at the Australian and New Zealand Schools of Planning Annual Conference, (Perth, September).

Hopkins, D. (2010) Planning a city through 'dialogue': deliberative democracy in action in Western Australia. Urban Policy and Research, 28(3), pp. 261-276.

Hopkins, D. (2008). Planning substance or political spin? Australian metropolitan planning in the $21^{\text {st }}$ Century, paper read at the Australian and New Zealand Schools of Planning Annual Conference, (Sydney, September).

Huxley, M. \& Yiftachel, O. (2000) New Paradigm or Old Myopia? Unsettling the Communicative Turn in Planning Theory, Journal of Planning Education and Research, 19, pp. 333-342.

IAP2. (2007) IAP2 Spectrum of Public Participation, downloaded 15 August 2008 from <http://www.iap2.org/associations/4748/files/IAP2\%20Spectrum_vertical.pdf>. 
Iedema, R. (1997) The language of administration: organizing human activity in formal institutions, in F. Christie \& J. R. Martin (eds.)_Genre and Institutions: Social Processes in the Workplace and School (London, Cassell).

Iedema, R. \& Grant, S. (2004) Revisiting Appraisal in the light of public-organisational discourse, or: the institutionalization of emotive meaning, paper read at the Annual conference of the Australian Systemic Functional Linguistics Association (Brisbane, September)

Innes, J. E. (1996) Planning Through Consensus Building: A New View of the Comprehensive Planning Ideal, Journal of the American Planning Association, 62(4), pp. 460-472.

Innes, J. E. (2004) Consensus building: clarifications for the critics, Planning Theory, 3(1), pp. $5-20$.

Innes, J. E. \& Booher, D.E. (2003) Collaborative policymaking: governance through dialogue, in Hajer and Wagenaar, (eds.).

Innes, J. \& Booher, D. E. (2010) Planning with Complexity: An Introduction to Collaborative Rationality for Public Policy (London, Routledge).

Jacobs, K. (2004) Waterfront redevelopment: A critical discourse analysis of the policy-making process within the Chatham Maritime Project, Urban Studies, 41, pp. 817-832.

Kumar, S. \& Pallathucheril V. G. (2004) Analyzing planning and design discourses, Environment and Planning B: Planning and Design, 31, pp. 829-846.

Lees, L. (2004) Urban geography: discourse analysis and urban research, Progress in Human Geography, 28(1), pp. 101-107.

MacCallum, D. (2008) Participatory Planning and Means-Ends Rationality: A Translation Problem? Planning Theory and Practice, 9(3), pp. 325-343.

MacCallum, D. (2009) Discourse Dynamics in Participatory Planning: Opening the Bureaucracy to Strangers (Aldershot, Ashgate). 
MacLachlan, G. \& Reid I. (1994) Framing and Interpretation (Melbourne, Melbourne University Press).

Martin, J. R. (1985). Process and Text: Two Aspects of Semiosis, in J. D. Benson and W. S. Greaves (eds.) Systemic Perspectives on Discourse, Vol. 1: Selected Theoretical Papers from the 9th International Systemic Workshop (Amsterdam, Benjamins).

Martin, J. R. (1992) English Text: System and Structure (Philadelphia, John Benjamins).

Martin, J. R. (1997) Analysing genre: functional parameters, in F. Christie and J. R. Martin (eds.) Genre and Institutions: Social Processes in the Workplace and School (London, Cassell).

McLoughlin, J. B. (1969) Urban and Regional Planning: A Systems Approach (London, Faber and Faber).

Metropolitan Region Planning Authority (1970) The Corridor Plan for Perth (Perth, Metropolitan Region Planning Authority).

Metropolitan Region Planning Authority (1972) Report on the Corridor Plan for Perth (Perth, Metropolitan Region Planning Authority).

Meyerson, M. \& Banfield, E. C. (1955) Politics, Planning and the Public Interest (Glencoe, The Free Press).

Myerson, G. \& Rydin, Y. (1994) 'Environment' and planning: a tale of the mundane and the sublime, Environment and Planning D: Society and Space, 12(4), pp. 437-452.

Osborne, D. \& Gaebler, T. (1992) Reinventing Government: How the Entrepreneurial Spirit is Transforming the Public Sector (Reading, Addison-Wesley).

Perth Regional Transport Study Steering Committee (1970) Perth Regional Transport Study (Perth, Western Australian Government).

Portugali, J. \& Alfasi N. (2008) An approach to planning discourse analysis, Urban Studies, 45, pp. 251-272. 
Pressman, J. L. \& Wildavsky, A. (1973) Implementation (Berkeley, University of California Press).

Review Group to the State Planning Commission (1987) Planning for the Future of the Perth Metropolitan Region (Perth, State Planning Commission of Western Australia).

Richardson, T. \& Jensen, O.B. (2003) Linking Discourse and Space: Towards a Cultural Sociology of Space in Analysing Spatial Policy Discourses, Urban Studies, 40(1), pp. 7-22.

Ritter, P. (1972) Report on an analytical study of the proposed corridor plan for Perth and possible alternate approach to a regional plan for the metropolitan area (Perth, MPRA).

Sandercock, L. (1976) Cities for Sale: Property, Politics and Urban Planning in Australia (London, Heinemann).

Sarangi, S. \& Slembrouck, S. (1996) Language, Bureaucracy and Social Control (London, Longman).

Searle, G. (2004) Planning discourses and Sydney's recent metropolitan strategies, Urban Policy \& Research, 22(4), pp. 367-91.

Searle, G. \& Bunker R. (2010) Metropolitan strategic planning: An Australian paradigm? Planning Theory, 9(3), pp. 163-180.

Searle, J. (1970) Speech Acts: An Essay in the Philosophy of Language (Cambridge, Cambridge University Press).

State of Western Australia (2009) Directions 2031: Draft Spatial Framework for Perth and Peel (Perth, Western Australian Planning Commission).

State of Western Australia (2010) Directions 2010 and Beyond: Metropolitan Planning Beyond the Horizon. (Perth, Department of Planning and Western Australian Planning Commission) Stephenson, G. \& Hepburn, J. (1955) Plan for the Metropolitan Region, Perth and Fremantle (Perth, Western Australian Government). 
Susskind, L., McKearnen S. and S. Thomas-Larmer S. (eds.) (1999) The Consensus Building Handbook: a Comprehensive Guide to Reaching Agreement (Thousand Oaks, Sage).

Taylor, N. (1998) Urban Planning Theory since 1945 (London, Sage).

Tett, A. \& Wolfe J. M. (1991) Discourse analysis and city plans, Journal of Planning Education and Research, 10(3), pp. 195-200.

Tewdwr-Jones, M. \& Allmendinger, P. (1998) Deconstructing communicative rationality: a critique of Habermasian collaborative planning, Environment and Planning A, 30, pp. 19751989.

Throgmorton, J. A. (1991) The rhetorics of policy analysis, Policy Sciences, 24(1), pp. 153-179.

Versteeg, W. \& Hajer, M. (2010) Is This How It Is, or Is This How It Is Here? Making Sense of Politics in Planning, in J. Hillier and P. Healey (eds.) The Ashgate Research Companion to Planning Theory: Conceptual Challenges for Spatial Planning (Aldershot, Ashgate).

Western Australian Planning Commission/Department for Planning and Infrastructure (2004) Network City: Community Planning Strategy for Perth and Peel (Perth, Western Australian Planning Commission).

Wildavsky, A. (1973) If Planning is Everything, Maybe it's Nothing, Policy Sciences, 4(2), pp. 127-53.

Yanow, D. (1996) How Does a Policy Mean? Interpreting Policy and Organizational Actions (Washington, Georgetown University Press).

Yiftachel, O. \& Hedgcock, D. (1992) Theoretical perspectives on Perth's changing urban form, in D. Hedgcock and O. Yiftachel (eds.) Urban and Regional Planning in Western Australia: Historical and Critical Perspectives (Perth, Paradigm Press).

Yiftachel, O. \& Huxley, M. (2000) Debating Dominance and Relevance: Notes on the 'Communicative Turn' in Planning Theory, International Journal of Urban and Regional Research, 24(4), pp. 907-913. 
Table 1: Analytical framework

\begin{tabular}{|c|c|c|}
\hline Key features & Specific questions & Resources \\
\hline $\begin{array}{l}\text { Representation of } \\
\text { Substance }\end{array}$ & $\begin{array}{l}\text { What does the plan 'do'? } \\
\text { How is information framed? } \\
\text { What kind of logic underpins the plan? } \\
\text { How are solutions presented? } \\
\text { What is shown to be problematic? } \\
\text { Where is the substantive detail? } \\
\text { How is space conceptualised? }\end{array}$ & $\begin{array}{l}\text { Transitivity } \\
\text { Appraisal } \\
\text { Conjunction } \\
\text { Collocation }\end{array}$ \\
\hline $\begin{array}{l}\text { Representation of } \\
\text { Agency }\end{array}$ & $\begin{array}{l}\text { Who is responsible for the authorship? } \\
\text { What is the role of planners/planning agencies? } \\
\text { How are human actors, including the public, } \\
\text { invoked? } \\
\text { Who are the agents of history? } \\
\text { Who will carry out the recommendations? }\end{array}$ & $\begin{array}{l}\text { Pronouns } \\
\text { Attribution/projection } \\
\text { Transitivity } \\
\text { Appraisal }\end{array}$ \\
\hline Generic Structure & $\begin{array}{l}\text { How does the plan unfold? } \\
\text { What themes are emphasised? } \\
\text { What connects different sections? }\end{array}$ & $\begin{array}{l}\text { Schema } \\
\text { Theme } \\
\text { Cohesion/Coherence }\end{array}$ \\
\hline Presentation & $\begin{array}{l}\text { What ideational and interpersonal messages are } \\
\text { conveyed by extra-linguistic elements of the text? } \\
\text { How are the author and reader positioned? } \\
\text { What does the layout draw attention to? } \\
\text { What is the purpose of the graphics? } \\
\text { How do the maps portray space and place? }\end{array}$ & $\begin{array}{l}\text { Layout } \\
\text { Colour } \\
\text { Graphics } \\
\text { Fonts/Formatting } \\
\text { Headlines } \\
\text { Highlighting }\end{array}$ \\
\hline
\end{tabular}


Table 2: Summary of CDA of the four Perth planning documents

\begin{tabular}{|c|c|c|c|c|c|}
\hline & $\begin{array}{l}\text { nature of the } \\
\text { plan }\end{array}$ & $\begin{array}{l}\text { institutional } \\
\text { roles }\end{array}$ & the public & $\begin{array}{l}\text { treatment of } \\
\text { space }\end{array}$ & $\begin{array}{l}\text { legitimacy } \\
\text { claims }\end{array}$ \\
\hline $\begin{array}{l}\text { Stephenson } \\
\text {-Hepburn }\end{array}$ & $\begin{array}{l}\text { blueprint for } \\
\text { future, high } \\
\text { degree of } \\
\text { control over } \\
\text { detail }\end{array}$ & $\begin{array}{l}\text { individuated } \\
\text { planner; } \\
\text { unproblematic } \\
\text { government }\end{array}$ & $\begin{array}{l}\text { idealised, the } \\
\text { principal } \\
\text { beneficiaries of } \\
\text { the plan }\end{array}$ & $\begin{array}{l}\text { flat, container for } \\
\text { land use functions }\end{array}$ & $\begin{array}{l}\text { author's } \\
\text { expertise; local } \\
\text { information; } \\
\text { projection } \\
\text { techniques }\end{array}$ \\
\hline Corridor & $\begin{array}{l}\text { interventionist } \\
\text { strategy, } \\
\text { shaping future } \\
\text { development }\end{array}$ & $\begin{array}{l}\text { institutional } \\
\text { planner; } \\
\text { invisible } \\
\text { government }\end{array}$ & invisible & $\begin{array}{l}\text { networked by } \\
\text { infrastructure }\end{array}$ & $\begin{array}{l}\text { scientific } \\
\text { method; } \\
\text { previous } \\
\text { transport study }\end{array}$ \\
\hline Metroplan & $\begin{array}{l}\text { reactive } \\
\text { strategy, } \\
\text { development } \\
\text { takes } \\
\text { precedence }\end{array}$ & $\begin{array}{l}\text { invisible } \\
\text { planner; } \\
\text { political } \\
\text { government }\end{array}$ & $\begin{array}{l}\text { political } \\
\text { constituents, } \\
\text { diverse in } \\
\text { personal needs } \\
\text { but agreed on } \\
\text { the issue of } \\
\text { economic } \\
\text { growth }\end{array}$ & $\begin{array}{l}\text { flat, but } \\
\text { organisable by } \\
\text { essentialist } \\
\text { hierarchies }\end{array}$ & $\begin{array}{l}\text { tacit consensus } \\
\text { on economic } \\
\text { growth; } \\
\text { consultation }\end{array}$ \\
\hline $\begin{array}{l}\text { Network } \\
\text { City }\end{array}$ & spatial strategy & $\begin{array}{l}\text { invisible } \\
\text { planner; } \\
\text { political } \\
\text { government }\end{array}$ & $\begin{array}{l}\text { conferred with } \\
\text { power/ } \\
\text { responsibility by } \\
\text { the planning } \\
\text { process. }\end{array}$ & $\begin{array}{l}\text { networked by } \\
\text { activities, but } \\
\text { containable }\end{array}$ & $\begin{array}{l}\text { Public } \\
\text { engagement }\end{array}$ \\
\hline $\begin{array}{l}\text { Directions } \\
2031\end{array}$ & spatial strategy & $\begin{array}{l}\text { institutional } \\
\text { planner, } \\
\text { political } \\
\text { government }\end{array}$ & $\begin{array}{l}\text { principally, as } \\
\text { beneficiaries of } \\
\text { the plan. } \\
\text { Conferred with } \\
\text { minor, } \\
\text { unspecified role } \\
\text { by process. }\end{array}$ & $\begin{array}{l}\text { networked by } \\
\text { activities and } \\
\text { infrastructure, } \\
\text { functionally } \\
\text { defined }\end{array}$ & $\begin{array}{l}\text { tacit consensus } \\
\text { on } \\
\text { sustainability } \\
\text { and specific } \\
\text { related } \\
\text { planning/ } \\
\text { development } \\
\text { principles; } \\
\text { consultation }\end{array}$ \\
\hline
\end{tabular}




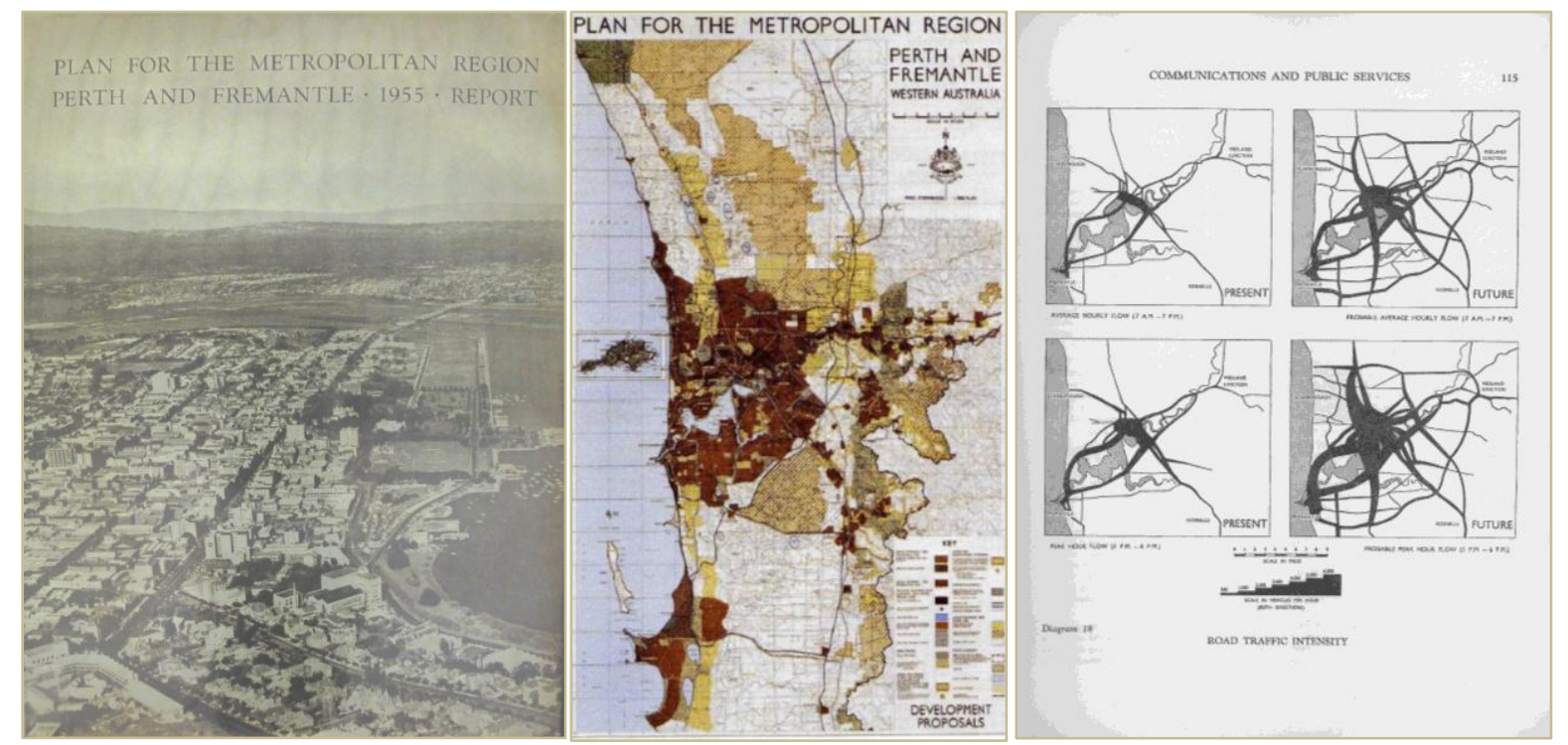

Figure 1: Cover, map and indicative page from Stephenson-Hepburn. Reproduced in accordance with the fair dealing exception for criticism and review (Copyright Act, s41) 

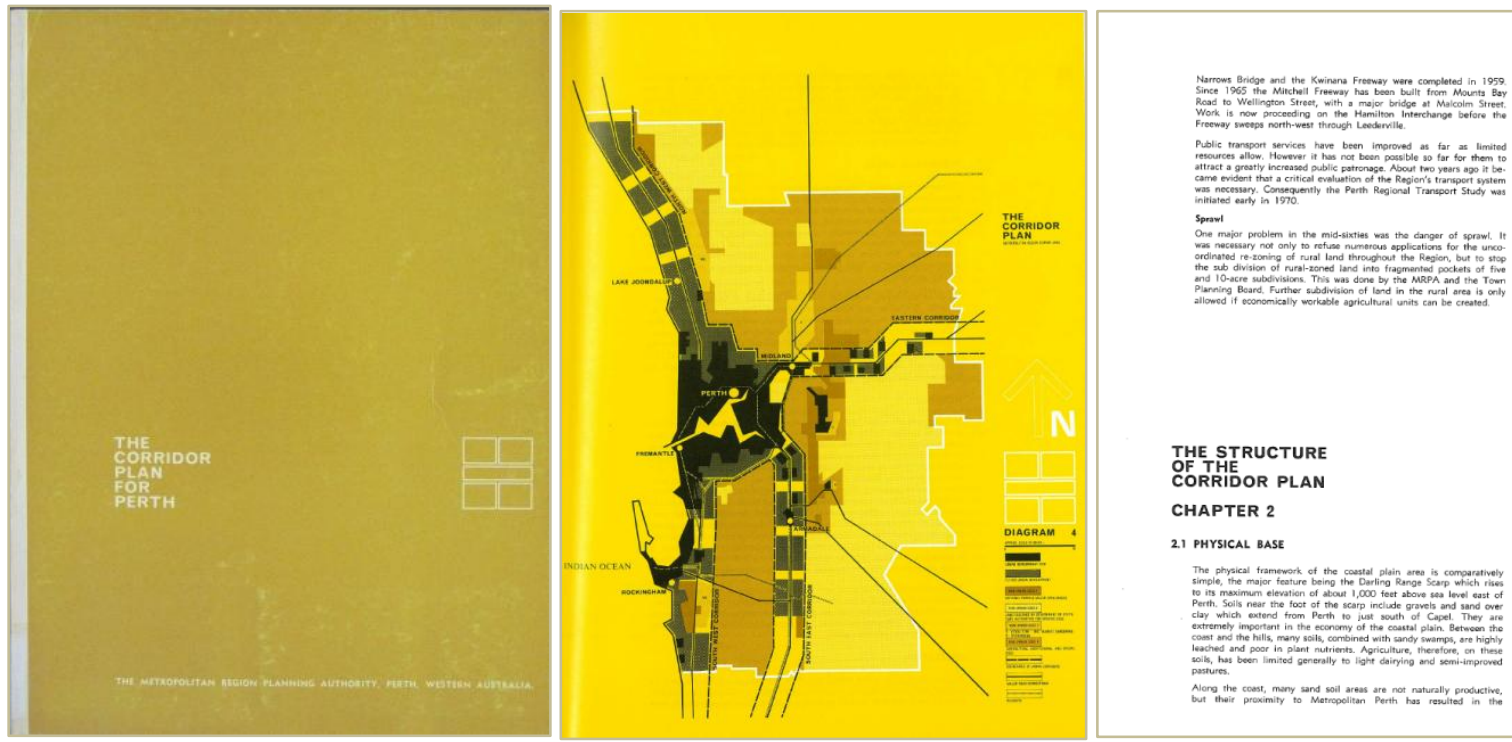

THE STRUCTURE CORRIDOR PLAN CHAPTER 2

21) PHYSICAL BASE

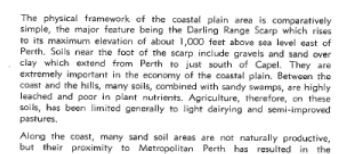

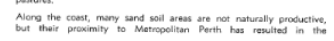

Figure 2: Cover, map and indicative page from the Corridor Plan. Reproduced in accordance with the fair dealing exception for criticism and review (Copyright Act, s41) 

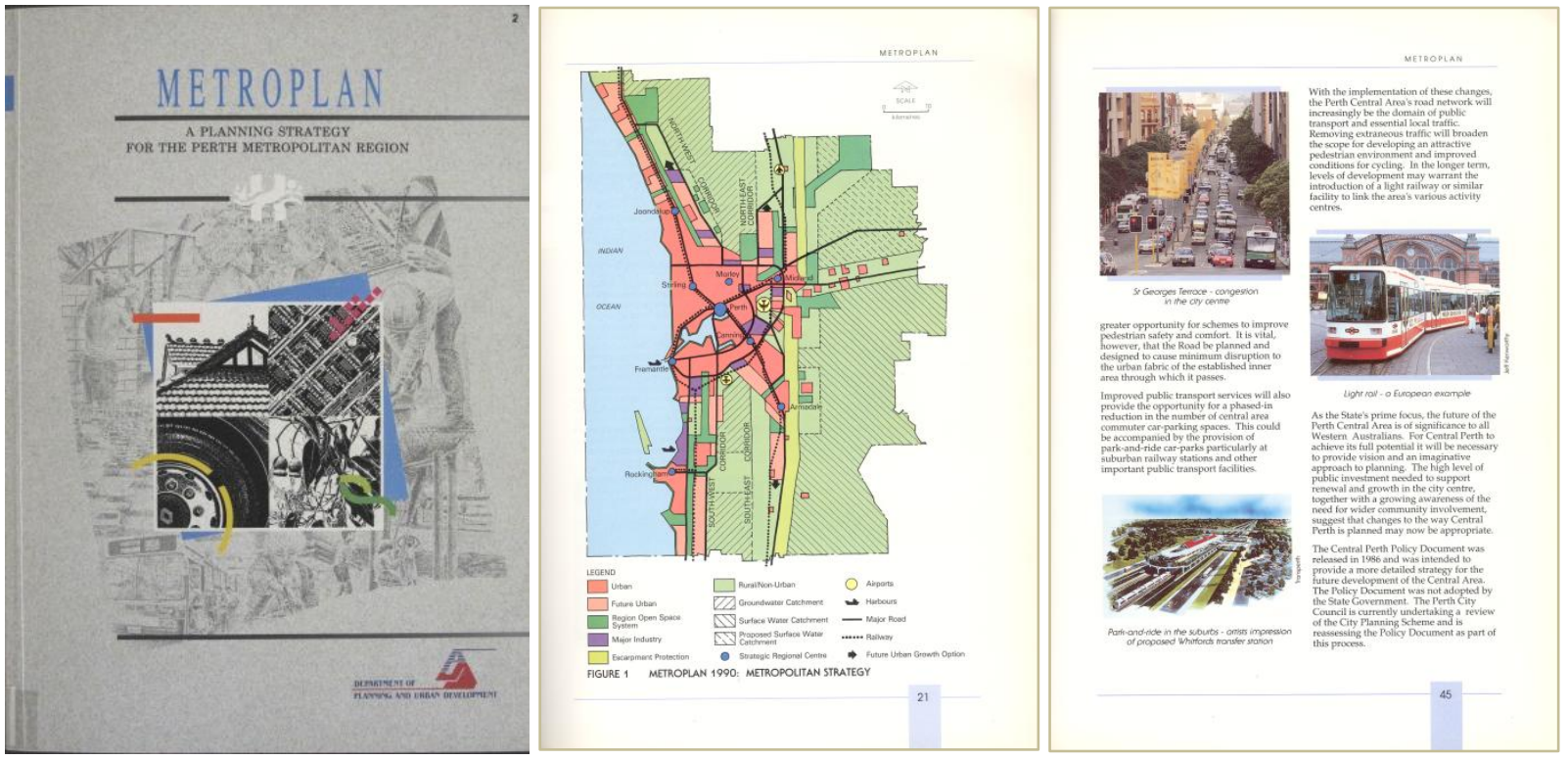

Figure 3: Cover, map and indicative page from Metroplan. Reproduced in accordance with the fair dealing exception for criticism and review (Copyright Act, s41). 

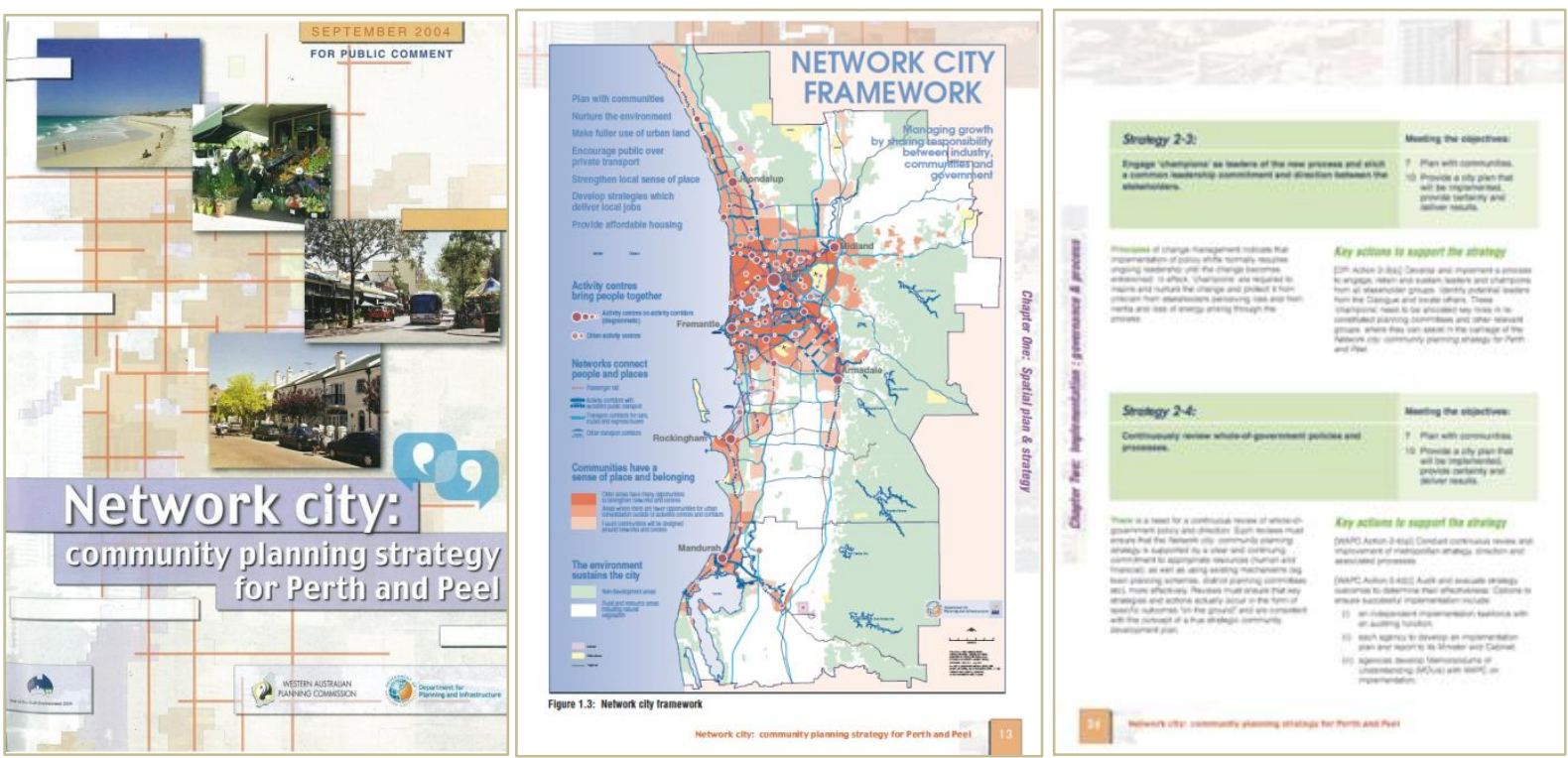

Figure 4: Cover, map and indicative page from Network City. Reproduced in accordance with the fair dealing exception for criticism and review (Copyright Act, s41). 


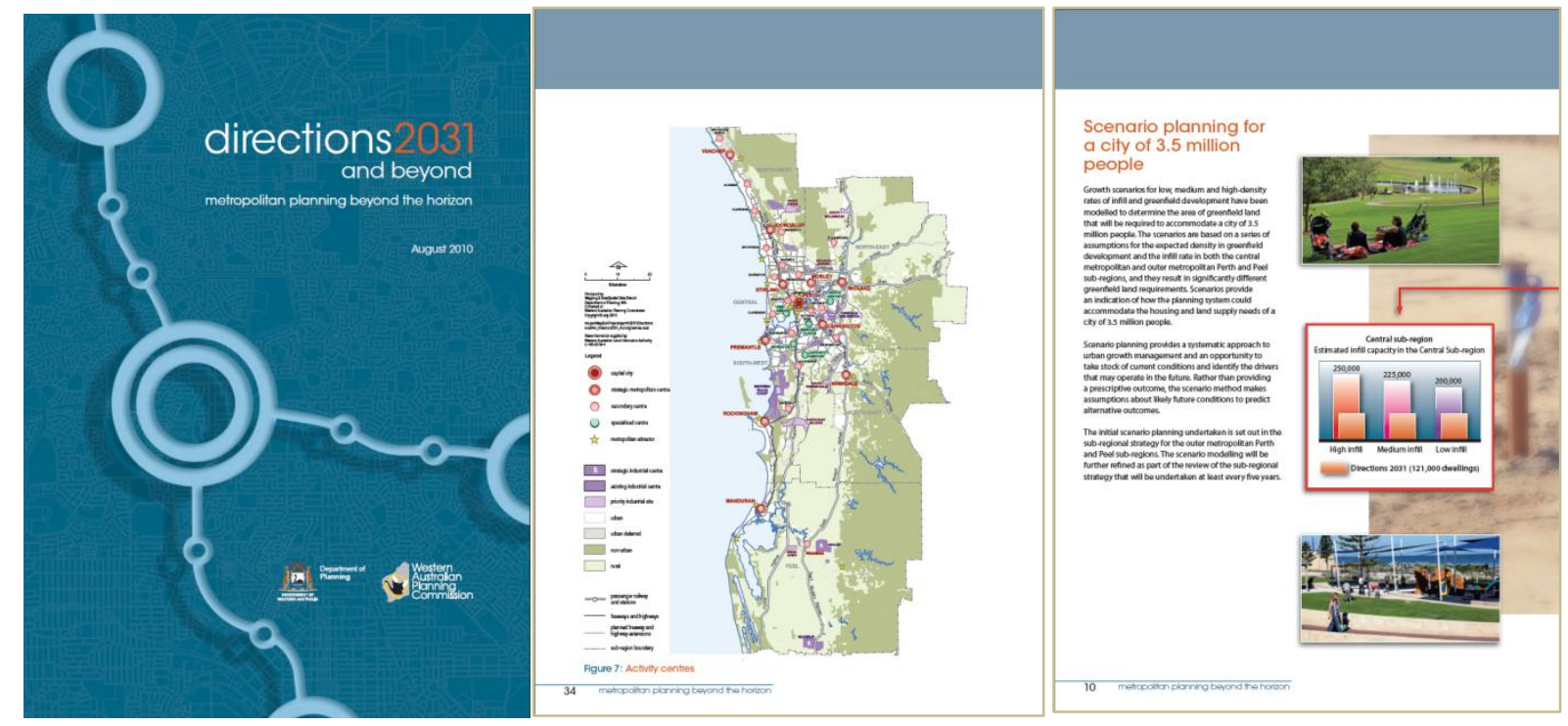

Figure 5: Cover, map and indicative page from Directions 2031. Reproduced in accordance with the fair dealing exception for criticism and review (Copyright Act, s41). 